\title{
Specific recognition and inhibition of Ewing tumour growth by antigen-specific allo-restricted cytotoxic $T$ cells
}

\author{
U Thiel', S Pirson', C Müller-Spahn', H Conrad², DH Busch³, H Bernhard ${ }^{2,4}$, S Burdach' and GHS Richter,, \\ 'Laboratory for Functional Genomics and Transplantation Biology, Children's Cancer Research Center and Department of Pediatrics, 81664 München, \\ Germany; ${ }^{2}$ III. Medizinische Klinik and Poliklinik (Hematology/Oncology), 81664 München, Germany; ${ }^{3}$ Institute of Microbiology, Immunology and Hygiene, \\ Roman Herzog Comprehensive Cancer Research Center and Klinikum rechts der Isar, Technische Universität München, 8I 664 München, Germany; \\ ${ }^{4}$ Department of Hematology/Oncology, Klinikum Darmstadt, 64283 Darmstadt, Germany
}

BACKGROUND: The development of a successful immunotherapy is hampered by an ineffective T-cell repertoire against tumour antigens and the inability of the patient's immune system to overcome tolerance-inducing mechanisms. Here, we test the specific recognition and lytical potential of allo-restricted $\mathrm{CD}^{+}{ }^{+} \mathrm{T}$ cells against Ewing tumour (ET) associated antigens Enhancer of Zeste, Drosophila Homolog 2 (EZH2), and Chondromodulin-I (CHMI) identified through previous microarray analysis.

METHODS: Following repetitive $\mathrm{CHMI}^{319}$ (VIMPCSWWV) and $\mathrm{EZH} 2^{666}$ (YMCSFLFNL) peptide-driven stimulations with HLA-A*020I ${ }^{+}$dendritic cells (DC), allo-restricted HLA-A*020I- CD8 ${ }^{+}{ }^{-}$cells were stained with HLA-A*020I/peptide multimers, sorted and expanded by limiting dilution.

RESULTS: Expanded $T$ cells specifically recognised peptide-pulsed target cells or antigen-transfected cells in the context of HLA-A*020 I and killed HLA-A*020 I ${ }^{+}$ET lines expressing the antigen while HLA-A*020 I- ET lines were not affected. Furthermore, adoptively transferred $T$ cells caused significant $E T$ growth delay in Rag $2^{-1-} \gamma_{C}{ }^{-1-}$ mice. Within this context, we identified the $\mathrm{CHMI}^{319}$ peptide as a new candidate target antigen for ET immunotherapy.

CONCLUSION: These results clearly identify the ET-derived antigens, EZH2666 and $\mathrm{CHMI}^{319}$, as suitable targets for protective allo-restricted human $\mathrm{CD}^{+}{ }^{+}$T-cell responses against non-immunogenic ET and may benefit new therapeutic strategies in ET patients treated with allogeneic stem cell transplantation.

British Journal of Cancer (20II) 1 04,948-956. doi:I0.1038/bjc.20II.54 www.bjcancer.com

(c) 20II Cancer Research UK

Keywords: Ewing tumour; cytotoxic $\mathrm{CD}^{+} \mathrm{T}$ cells; immunotherapy; adoptive transfer; multimer technology

T-cell based tumour immunology suffers from a principal dilemma: tumour-derived peptides are frequently self-antigens associated with MHC class I molecules. Moreover, T cells with high affinity for such antigens undergo negative selection and peripheral tolerance mechanisms diminish their number or eliminate self-peptide specific cytotoxic T cells. Nevertheless, as the T-cell repertoire has not been educated to ignore self antigens presented by foreign MHC molecules, allo-restricted $\mathrm{T}$ cells may represent a comprehensive repository for tumourspecific T cells (Felix and Allen, 2007).

Allogeneic stem cell transplantation (SCT) is an established treatment for leukaemia where donor $\mathrm{T}$ cells induce a graft- $v s$ leukaemia response that can eradicate residual malignant cells (Kolb et al, 1995), and is now being explored as a treatment for a variety of other haematologic and non-haematologic malignancies (Childs et al, 2000). For malignant peripheral neuroectodermal tumours (Ewing tumour, ET), patients with vast bone affection and poor prognosis, allogeneic SCT represents a therapy option (Burdach et al, 2000, 2009). Koscielniak et al (2005) and Lucas et al (2008) reported tumour regression in ET patients with advanced disease immediately after allogeneic SCT. This possible graft- $v s$-ET

*Correspondence: Dr GHS Richter, E-mail: somagene@Irz.tum.de Received 21 December 2010; revised 13 January 2011; accepted 4 February 201 I effect, however, may be associated with a pronounced toxicity potential of a graft- $v s$-host response in this therapeutic approach.

During the past years, methods emerged to identify, isolate, and expand tumour peptide-specific allo-restricted $\mathrm{T}$ cells ex vivo (Moris et al, 2001; Dutoit et al, 2002; Mutis et al, 2002; Amrolia et al, 2003; Whitelegg et al, 2005; Schuster et al, 2007), anticipating their potential use for adoptive immunotherapy (Rosenberg et al, 2008) for example, to replace common donor lymphocyte infusion (DLI) with tumour-specific allo-restricted $\mathrm{T}$ cells. We describe here, an HLA-A ${ }^{\star} 0201$-multimer approach using peptides derived from genes identified to be overexpressed in ET by microarray analysis (Staege et al, 2004). These peptide/MHC multimers enabled the selection of allo-restricted tumour-antigen specific $\mathrm{T}$ cells from an allo-reactive T-cell pool. Such T cells were peptidespecific and cytotoxic against ET cells with the appropriate HLA-expression and significantly delayed tumour growth after adoptive transfer in a xenograft mouse model.

\section{MATERIALS AND METHODS}

\section{Cell lines}

MHHES1, SK-ES1, SK-N-MC, TC71 (ET cell lines), CHP126, MHHNB11, SH-SY5Y, SIMA (neuroblastoma cells), and NALM6, 697, cALL2 (paediatric human B-cell precursor leukaemic lines) 
were obtained from the German Collection of Microorganisms and Cell Cultures (DSMZ; Braunschweig, Germany). The HLA$\mathrm{A}^{\star} 0201^{+}$melanoma cell line SK-MEL29 was provided by L Old (Memorial Sloan-Kettering Cancer Institute, New York, NY, USA). A673 (ET cells) and Cos-7 (Simian SV40-transformed fibroblasts) were obtained from ATCC (LGC Standards GmbH, Wesel, Germany), the TAP-defective $\mathrm{HLA}^{\star} \mathrm{A} 0201^{+} \mathrm{T} 2$ cell line (LCL somatic cell hybrid) was from P Cresswell (Yale University School of Medicine, New Haven, CT, USA). The HLA-A ${ }^{\star} 0201^{-}$erythroid leukaemia cell line K562 was a gift from A Knuth and E Jäger (Krankenhaus Nordwest, Frankfurt, Germany). HLA-A*0201SBSR-AKS ET cells were described previously (Richter et al, 2009). All cell lines are routinely tested for purity (e.g., translocation product, surface antigen or HLA-phenotype) and mycoplasma contamination. Lymphoblastoid cell lines (LCL) were generated by EBV transformation of peripheral blood $B$ cells from HLA-A ${ }^{\star} 0201^{+}$healthy donors by use of a mini-EBV plasmid (Moosmann et al, 2002). The supernatant was provided by Josef Mautner and Andreas Moosmann, Helmholtz-Zentrum München. Tumour cell lines including K562 cells were cultured in RPMI 1640 or DMEM (only Cos-7 and SK-Mel29; Life Technologies, Paisley, Scotland) supplemented with $10 \%$ foetal calf serum (FCS, Biochrom, Berlin, Germany), $100 \mathrm{U} \mathrm{ml}^{-1}$ penicillin, $100 \mu \mathrm{g} \mathrm{ml}^{-1}$ streptomycin, and $2 \mathrm{~mm}$ glutamine (all from Life Technologies). RPMI 1640 medium for LCL and T2 cells was supplemented with $10 \%$ human $\mathrm{AB}$ serum, $2 \mathrm{~mm}$ L-glutamine, $1 \mathrm{~mm}$ Na-pyruvate, nonessential amino acids, and $50 \mu \mathrm{g} \mathrm{ml}^{-1}$ gentamycine (all from Life Technologies).

\section{Isolation of PBMC}

Peripheral blood mononuclear cells (PBMCs) were isolated from human peripheral blood samples of healthy donors (obtained with IRB approval and informed consent from the DRK-Blutspendedienst Baden-Württemberg-Hessen in Ulm, Germany) by centrifugation over Ficoll-Paque (GE Healthcare, Freiburg, Germany) according to the supplier's recommendations.

\section{Generation of dendritic cells (DCs)}

$\mathrm{CD}_{14}{ }^{+}$cells were isolated from PBMCs with anti-human CD14 magnetic particles (BD Biosciences, Heidelberg, Germany) according to the manufacturer's instructions. Purity of cells was confirmed by flow cytometry on a FACS Calibur (BD Biosciences).

$\mathrm{CD}_{14}{ }^{+}$monocytes were cultured in X-Vivo15 (Biowhittaker/ Cambrex Bio Science Verviers, Apen, Germany)/1\% AB serum (Biowhittaker/Cambrex) with $1000 \mathrm{IU} \mathrm{ml}^{-1} \mathrm{IL}-4$ (R\&D Systems, Wiesbaden, Germany) and $800 \mathrm{IU} \mathrm{ml}^{-1}$ GM-CSF (Leukine sargramostim, Bayer Health Care, Leverkusen, Germany) at a concentration of $3 \times 10^{5} \mathrm{ml}^{-1}$ with $25-30 \mathrm{ml}$ per $75 \mathrm{~cm}^{2}$ cell culture flask (TPP, Trasadingen, Switzerland) at $37^{\circ} \mathrm{C}$ and $5 \% \mathrm{CO}_{2}$. On day 3 , cytokines were replaced. On day 6 of culture, DC maturation was induced by adding a cytokine cocktail consisting of $10 \mathrm{ng} \mathrm{ml}^{-1}$ $\mathrm{TNF} \alpha, 10 \mathrm{ng} \mathrm{ml}^{-1} \mathrm{IL}-1 \beta, 1000 \mathrm{IU} \mathrm{ml}^{-1}$ IL-6 (R\&D Systems), and $1 \mu \mathrm{g} \mathrm{ml}^{-1} \mathrm{PGE}_{2}$ (Cayman Europe, Tallin, Estonia). On culture day 8 and 9, cells displayed a mature phenotype as evidenced by flow cytometry. DCs were considered mature when positive for CD86, CD83, and HLA-DR.

\section{Isolation of $\mathrm{CD8}^{+} \mathrm{T}$ cells}

Untouched $\mathrm{CD}^{+}{ }^{+} \mathrm{T}$ cells were purified from human HLA-A ${ }^{*} 0201^{-}$ PBMCs by negative isolation technique using a cocktail of biotinconjugated non-CD8 monoclonal antibodies and anti-biotin micro beads followed by depletion of magnetically labelled cells on LS columns (all from Miltenyi Biotec, Bergisch Gladbach, Germany). Purity of isolated CD8 ${ }^{+}$T cells was confirmed by flow cytometry.

\section{In vitro priming}

Mature DCs were resuspended in T-cell medium (AIM-V supplemented with $5 \%$ human $\mathrm{AB}$ serum, $2 \mathrm{mM}$ L-glutamine, and $50 \mu \mathrm{g} \mathrm{ml}^{-1}$ gentamycine) and pulsed with selected peptides at a concentration of $30-50 \mu \mathrm{M}$ in the presence of $20 \mu \mathrm{g} \mathrm{ml}^{-1} \beta_{2} \mathrm{M}$ (Sigma, Taufkirchen, Germany) for $4 \mathrm{~h}$ at $37^{\circ} \mathrm{C}$ and $5 \% \mathrm{CO}_{2}$ washed and were then irradiated at $35 \mathrm{~Gy}$, and used for $\mathrm{T}$-cell priming immediately or stored in liquid nitrogen for subsequent experiments. $\mathrm{CD} 8{ }^{+} \mathrm{T}$ cells from an $\mathrm{HLA}-\mathrm{A}^{*} 0201^{-}$donor were stimulated with allogeneic HLA-A ${ }^{*} 0201^{+}$DCs in $200 \mu$ l of T-cell medium in a stimulator to responder rate of $1: 20\left(5 \times 10^{3} \mathrm{DCs}\right.$ per well $: 10^{5} \mathrm{CD}^{+} \mathrm{T}$ cells per well). For priming, $\mathrm{T}$ cells and DCs were co-cultured with $10 \mathrm{ng} \mathrm{ml}^{-1}$ rhIL-12 and $1000 \mathrm{U} \mathrm{ml}^{-1}$ rhIL- 6 and after 1 week were restimulated with the same number of loaded $\mathrm{DCs}$ in the presence of $5 \mathrm{ng} \mathrm{ml}^{-1}$ rhIL-7 and $100 \mathrm{U} \mathrm{ml}^{-1}$ rhIL-2.

\section{Multimer-staining and cell sorting}

Two weeks after the beginning of in vitro priming all activated $\mathrm{T}$ cells were pooled and stained with a specific peptide/

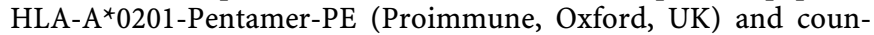
terstained with an anti-human CD8-FITC mAb (BD Biosciences) for cell sorting. Isotype IgG $\mathrm{mAb}$ and irrelevant peptide/

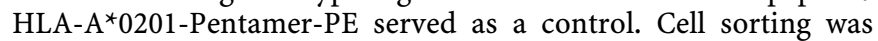
executed on a FACS Aria (BD Biosciences).

\section{$\mathrm{V} \beta$ analysis of $\mathrm{T}$-cell receptor repertoire}

To determine the status of clonality of T-cell clones, the IOTest Beta Mark Kit (Beckman Coulter, Brea, CA, USA) was used. This kit is designed for flow cytometric determination of the T-cell receptor (TCR) V $\beta$ repertoire of human T lymphocytes and allows testing for 24 different $\mathrm{V} \beta$ specificities that cover about $70 \%$ of the normal human TCR V $\beta$ repertoire.

\section{Limiting dilution}

After purifying peptide-specific $\mathrm{T}$ cells through peptide/ HLA-A ${ }^{\star} 0201$-multimer-mediated cell sorting, isolated T cells were expanded using limiting dilution. Expansion was conducted in round-bottom 96-well plates in $200 \mu \mathrm{l} \mathrm{T}$-cell medium supplemented with anti-CD3 $\left(30 \mathrm{ng} \mathrm{ml}^{-1}\right)$, rhIL-2 $\left(50 \mathrm{IU} \mathrm{ml}^{-1}\right)$, rhIL-15 $\left(2 \mathrm{ng} \mathrm{ml}^{-1}\right)$, irradiated LCL; $1 \times 10^{5}$ per well and irradiated PBMCs pooled from three different healthy donors $\left(5 \times 10^{4}\right.$ per well) as feeder cells as previously described (Parker et al, 1994). Cytokines and $100 \mu \mathrm{l}$ medium/well were replaced after 1 week. Expanded $\mathrm{T}$ cells were further characterized in ELISpot assays.

\section{ELISpot-assay}

The 96-well mixed cellulose ester plates (MultiScreen-HA Filter Plate, $0.45 \mu \mathrm{m}$, Millipore, Eschborn, Germany) were coated overnight at $4{ }^{\circ} \mathrm{C}$ with $50 \mu$ l per well of capture antibody solution (all Mabtech, Hamburg, Germany, Supplementary Table SII) in PBS. Plates were then washed four times with PBS and subsequently blocked with $150 \mu \mathrm{l}$ per well of TCM for $1 \mathrm{~h}$ at $37^{\circ} \mathrm{C}$. When peptide-loaded T2 cells were used, they were preincubated with $30-50 \mu \mathrm{m}$ peptide for at least $2 \mathrm{~h}$ at $37^{\circ} \mathrm{C}$. When ET cells were used, they were pre-incubated with $100 \mathrm{U} \mathrm{ml}^{-1} \mathrm{IFN}-\gamma$ $48 \mathrm{~h}$ before use in the assay. After blocking, the $\mathrm{T}$ cells to be investigated were either adjusted at a concentration of $2 \times 10^{6}$ cells $\mathrm{ml}^{-1}$ in TCM and $50 \mu \mathrm{l}$ of serial dilutions (Granzyme B) or $50 \mu \mathrm{l}$ containing $1000 \mathrm{~T}$ cells (IFN- $\gamma$ ) were plated into the wells and incubated for $30 \mathrm{~min}$ at $37^{\circ} \mathrm{C}$. The target cells were washed, resuspended in TCM and $50 \mu \mathrm{l}$ per well allocated per well containing 20000 cells. For HLA-A ${ }^{\star} 0201$ blocking of A673, the HLA class I (W6/32) specific antibody (Abcam, Cambridge, UK) 
was added to the wells at a concentration of $10 \mu \mathrm{g} \mathrm{ml}^{-1}$. Peripheral blood mononuclear cells (PBMCs) isolated from an HLA-A ${ }^{*} 0201^{+}$ healthy donor were either stimulated with $3 \mu \mathrm{g} \mathrm{ml}^{-1}$ OKT3 for $48 \mathrm{~h}$ or left untreated. Before application to the assay, cells were irradiated with $30 \mathrm{~Gy}$ and washed thrice with PBS. The plates were then incubated for $20 \mathrm{~h}$ at $37^{\circ} \mathrm{C}$. Subsequently, the plates were washed six times with $\mathrm{PBS} / 0.05 \%$ Tween 20 (Sigma). Then wells were incubated for $2 \mathrm{~h}$ at $37^{\circ} \mathrm{C}$ with $200 \mu \mathrm{l}$ of biotinylated secondary antibody (all Mabtech, Supplementary Table S2) diluted in $\mathrm{PBS} / 0.5 \%$ BSA. The plates were washed six times with PBS/0.05\% Tween 20. A volume of $200 \mu$ l per well of StreptavidinHRP (Mabtech) diluted 1/1000 was added and plates were incubated for $1 \mathrm{~h}$ at RT. After three washes with PBS/0.05\% Tween 20 followed by three final washes with PBS, $100 \mu$ l of 3-Amino-9ethyl-carbazole solution (Sigma) was added and incubated for 4-8 min. Colour-development was stopped by washing under running tap water. Spots in dried plates were counted on an AIDELIRIFL04 ELISpot reader (Autoimmun Diagnostika, Strassberg, Germany).

\section{Tumour challenge and adoptive $\mathrm{T}$-cell transfer in Rag2 ${ }^{-l-} \gamma_{\mathrm{C}}{ }^{-l-}$ mice}

Immunodeficient $\mathrm{Rag} 2^{-1-} \gamma_{\mathrm{C}}^{-l-}$ mice on a BALB/c background were obtained from the Central Institute for Experimental Animals (Kawasaki, Japan). Mice were bred and maintained in our animal facility under pathogen-free conditions in accordance with the institutional guidelines and approval by local authorities. Each mouse was challenged by s.c. intra-inguinal injection of $2 \times 10^{6}$ A673 ET cells and monitored for tumour growth. Three days after tumour challenge, each mouse received either $2 \times 10^{6}$ EZH2-15 $(n=7)$ or $2 \times 10^{6}$ CHM1-6 $(n=6)$ T cells intravenously or were left untreated (control group, $n=8$ ). At 17 days after tumour challenge, mice were killed and analysed for tumour weight.

\section{RESULTS}

Histone methyltransferase EZH2 and chondromodulin-I are strongly upregulated in Ewing tumours

The EWS-FLI1 fusion protein, which is pathognomonic in $85 \%$ of ET, represents an ideal immunological target in search of immunogenic peptides for T-cell based therapy. However, we were not able to validate any peptide from this fusion region as a good binder to, for example, HLA-A*0201 (Meyer-Wentrup et al, 2005). Therefore, we reinforced our endeavours to identify cytotoxic T-cell epitopes of other antigens that are specifically expressed in ET. In a previous microarray analysis, we recognised the histone (lysine) methyl-transferase Enhancer of Zeste, Drosophila, Homolog 2 (EZH2) and Chondromodulin-I (CHM1) as strongly upregulated genes in ET (Staege et al, 2004) and demonstrated that EZH2 has a critical role in ET pathology by determining the oncogenicity and stem cell phenotype of this tumour (Richter et al, 2009). As shown in Figure 1A, CHM1 expression was not observed in any normal tissue analyzed, whereas EZH2 is expressed ubiquitously at low levels, with elevated levels in bone marrow, rectum, testis, and thymus. In addition, real-time RT-PCR demonstrated that other childhood malignancies including common acute lymphoblastic leukaemia (cALL) and neuroblastoma showed a significantly lower or no expression of CHM1 and EZH2, respectively (Figure 1B).

\section{Selection of HLA-A ${ }^{\star 0201-r e s t r i c t e d ~ p e p t i d e s ~ d e r i v e d ~}$ from ET antigens}

HLA-A ${ }^{\star} 0201$ epitope binding analyses and presumed proteasomal cleavage prediction were performed by use of SYFPEITHI (Rammensee et al, 1999), BIMAS (Parker et al, 1994), and NetCTL
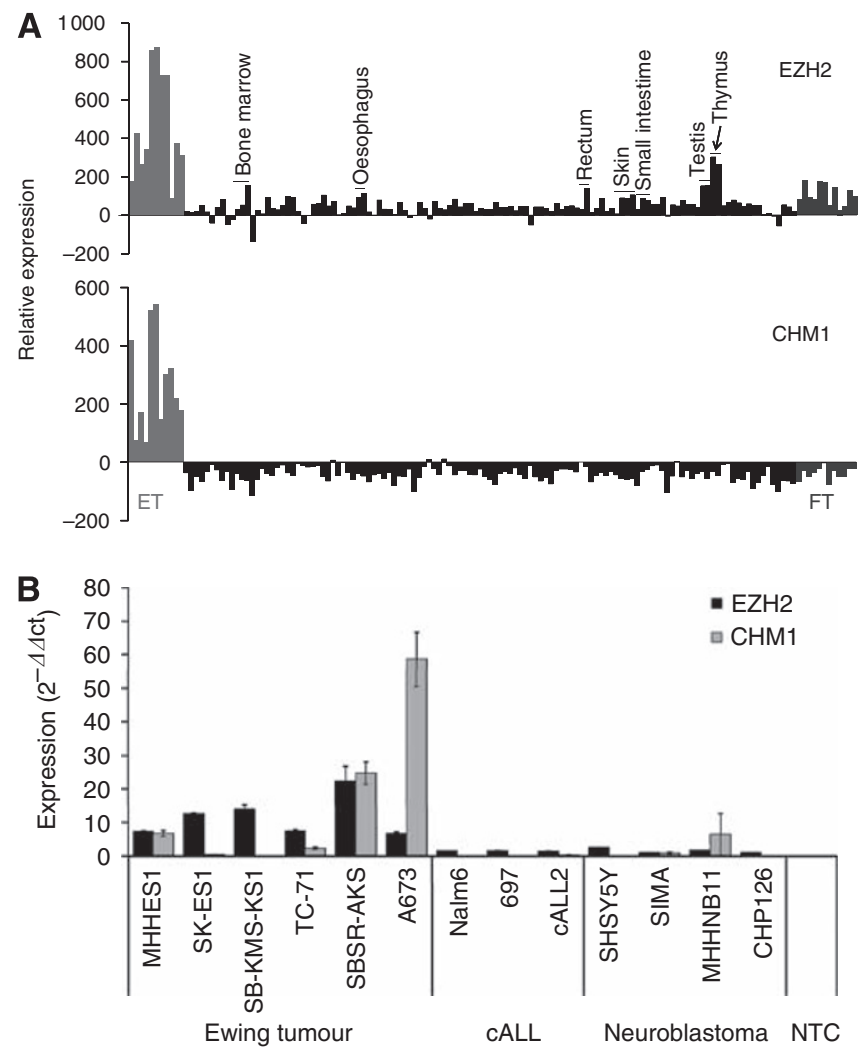

Figure I Antigen-specific expression profile (gray). (A) Expression profile of $\mathrm{EZH} 2$ and $\mathrm{CHMI}$ in Ewing tumours (ET, red) in comparison to normal (black), and foetal tissue (FT, gray). Ewing tumour, FT and normal tissue samples were analyzed using EOS-HuOl microarrays (Staege et al, 2004). (B) Expression of $\mathrm{EZH} 2$ and $\mathrm{CHMI}$ was evaluated by real-time RT-PCR in different paediatric tumour cell lines. Error bars represent s.d. of triplicate experiments. Abbreviation: NTC= non-template control.

(Larsen et al, 2005) algorithms (see Supplementary Information). Selected peptides and their scores are shown in Supplementary Table SI. Synthesised peptides were validated for binding to HLA$A^{\star} 0201$ onto T2 cells. Peptide dependent increase of HLA-A*0201 expression measured by flow cytometry is shown (Supplementary Figure 1). Specific binding was correlated to influenza matrix peptide (GILGFVFTL) binding. Peptide CHM1 $1^{319}$ and previously published peptide EZH2 ${ }^{666}$ (Steele et al, 2006) demonstrated strong HLA-A ${ }^{\star} 0201$ binding whereas peptide $\mathrm{CHM1}^{38}$ revealed no binding at all in this assay. Peptides $\mathrm{CHM}^{319}$ and $\mathrm{EZH} 2{ }^{666}$ were chosen for subsequent in vitro priming of $\mathrm{T}$ cells.

\section{Selection of peptide- and ET-specific T cells}

Although autologous HLA-A*0201 restricted $\mathrm{CD}^{+} \mathrm{T}$ cells specific for either $\mathrm{EZH} 2^{666}$ or $\mathrm{CHM}^{319}$ peptide were easily identified, they were in no case able to recognise HLA-A ${ }^{\star} 0201^{+}$ ET cells (Supplementary Figure 2). Therefore, we focused our attention on the establishment of peptide-specific allo-restricted T cells. For this purpose, in vitro generated, mature HLA-A ${ }^{\star} 0201^{+}$ DC were pulsed with either CHM1 $1^{319}$ or EZH2 $2^{666}$, which were then used to stimulate purified HLA-A ${ }^{*} 0201^{-} \mathrm{CD}^{+} \mathrm{T}$ cells twice in a 7-day interval (see Materials and Methods). Subsequently, to separate allo-reactive CTL from allo-restricted CTL, peptide/ HLA-A ${ }^{\star} 0201^{+}$multimers were used to label allo-restricted CD8 ${ }^{+}$ $\mathrm{T}$ cells (Borg et al, 2005). The CTL peptide/HLA-A*0201 ${ }^{+}$ multimer staining was highly specific and usually stained only between $0.1-0.4 \%$ cells of the stimulated T-cell population. Peptide-multimer-positive T cells were sorted by FACS. Figure 2A 
provides an example of these marginal T-cell populations that were positive for both peptide/HLA- ${ }^{\star} 0201$-multimer and CD8, here specifically stained with the $\mathrm{CHM}^{319} /$ multimer. Subsequently, sorted $\mathrm{T}$ cells were expanded using limiting dilution and tested for specificity in ELISpot assays.

In a first screen, the expanded $\mathrm{T}$-cell lines were tested for specific IFN- $\gamma$ release against individual peptides: T2 cells were either pulsed with $\mathrm{CHM} 1^{319}$ or $\mathrm{EZH} 2^{666}$, or the influenza-derived peptide (GILGFVFTL) as a control. For example, of the $\mathrm{T}$ cells initially specifically selected with the $\mathrm{CHM}^{319} / \mathrm{HLA}-\mathrm{A}^{\star} 0201$ multimer, 96 cell $\gamma$ release against CHM1 lines were grown and tested for specific IFN- ${ }^{319}$ peptide. The results of seven lines are shown in Figure 2B, left. One line that passed this screen (CHM1-6) was further expanded and retested on T2 cells (Supplementary Figure 3, left) as well as Cos-7 cells, which were double-transfected with an HLA-A ${ }^{\star} 0201$ expression plasmid and a CHM1 cDNA encoding vector, confirming specific recognition and peptide presentation $(P=0.01$, two-tailed $t$-test; Figure $2 \mathrm{C}$, left). Furthermore, subsequent analysis demonstrated correct HLA-A ${ }^{*} 0201$ restricted recognition of ET cell lines $(P=0.007$, two-tailed $t$-test; Figure $2 \mathrm{C}$, right). A similar screen for $\mathrm{T}$ cells specific for $\mathrm{EZH} 2^{666}$ peptide identified three lines EZH2-11, -15, and -24 with peptidespecific recognition on $\mathrm{T} 2$ cells (Figure $2 \mathrm{~B}$, right). One line that was further expanded and repeatedly tested (Supplementary Figure 3 , right), revealed specific recognition of processed EZH2 ${ }^{666}$ peptide on double-transfected Cos-7 cells $(P=0.008$, two-tailed $t$-test; Figure 2C, left) and HLA-A ${ }^{\star} 0201$ specific identification of ET lines ( $P=0.002$, two-tailed $t$-test; Figure $2 \mathrm{C}$, right). In flow cytometry, these two lines CHM1-6 (specific for $\mathrm{CHM}^{319}$ ) and $\mathrm{EZH} 2-15$ (specific for $\mathrm{EZH} 2^{666}$ ) were only positive for $\mathrm{V} \beta 13.2$ (CHM1-6) or $\mathrm{V} \beta$ 13.1 (EZH2-15) (data not shown). Both lines stained positive with their respective peptide/HLA-A*0201-multimer (Figure 2D) and were CD27 $7^{\text {low }}, \mathrm{CD} 28^{-}, \mathrm{CD} 45 \mathrm{RA}^{\text {low }}, \mathrm{CD}^{+} 6^{+}$, $\mathrm{CD}^{2} \mathrm{~L}^{-}, \mathrm{IL7R}^{-}, \mathrm{CCR}^{-}$, and $\mathrm{CCR}^{-}$(data not shown).

\section{Allo-restricted T cells mediate Ewing tumour-specific cytotoxicity}

To test for ET specific cell-mediated cytotoxicity of allo-restricted T-cell lines, we investigated their ability for antigen-specific granzyme B release in the ELISpot assay (Shafer-Weaver et al, 2003; Anderson et al, 2007). Both T-cell lines demonstrated a specific granzyme $\mathrm{B}$ release only when tested in the appropriate antigen/HLA-A ${ }^{\star} 0201$-restriction combination, while HLA-A ${ }^{\star} 0201^{-}$ET cells recognition (SBSR-AKS cells) and possible NK-cell activity, as tested on K562 cells, was not higher than background level of pure T cells (overall $P<0.05$ until effector to target ratio reached 1.25 , Welch two sample $t$-test; Figures $3 \mathrm{~A}$ and $B$ ). Retesting at a fixed effector to target ratio of 10:1 only identified a significant granzyme B release when these T-cell lines recognised HLA-A ${ }^{\star} 0201^{+}$ET cells (all $P<0.05$; two-tailed $t$-test; Figure 3C). HLA-restricted recognition was reversed after blocking with an HLA-A ${ }^{\star} 0201$ blocking antibody. Furthermore, HLA$\mathrm{A}^{\star} 0201^{+} \mathrm{PBMC}$ or OKT3 activated, HLA-A ${ }^{\star} 0201^{+} \mathrm{T}$ cells where
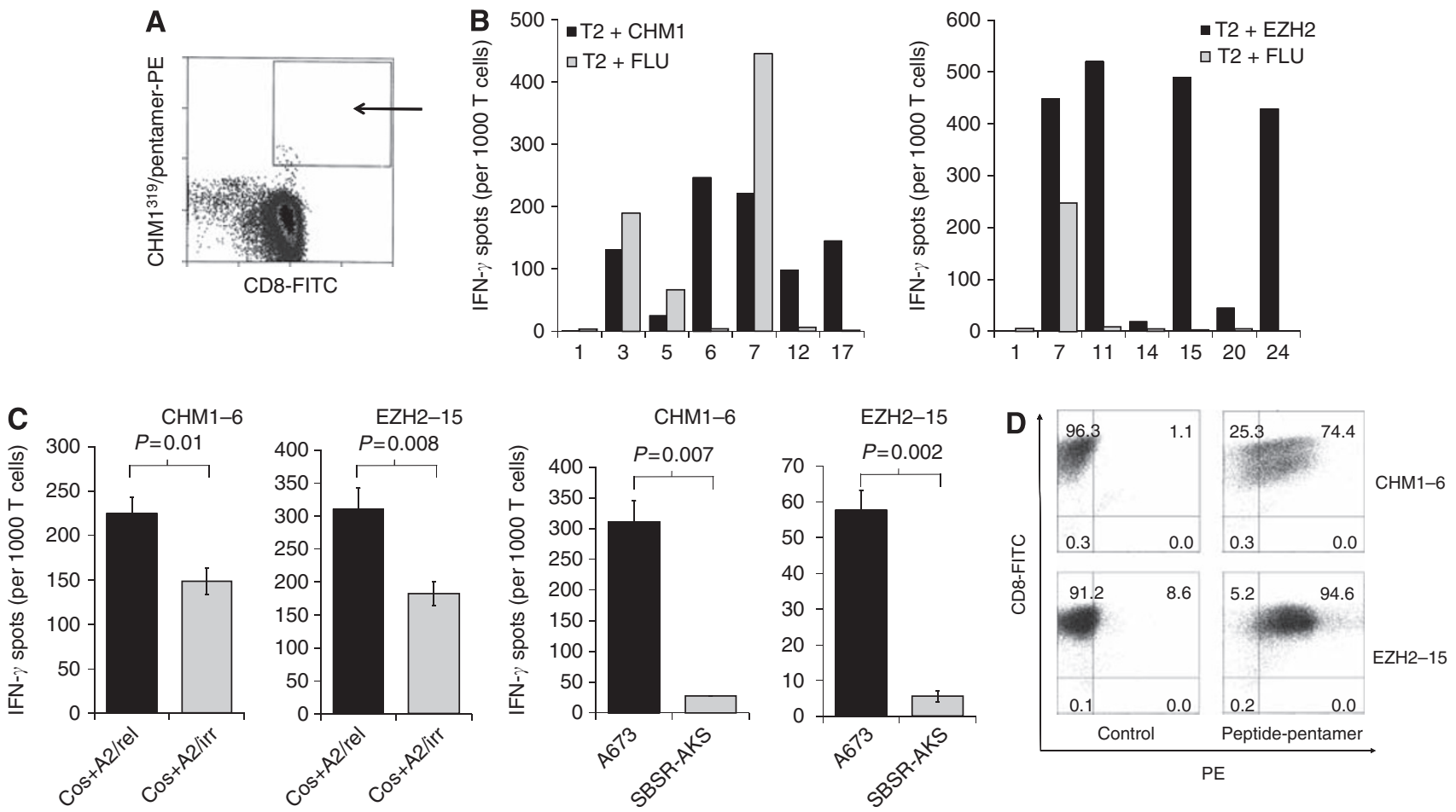

Figure 2 Selection and antigen-specificity of allo-restricted T cells. (A) The CD8 ${ }^{+}$Peptide-HLA-A*020I-multimer ${ }^{+} \mathrm{T}$ cells were sorted by flow cytometry directed cell sorting. An example for $\mathrm{CHMI}^{319}$-peptide-specific T cells is given: 1560 cells of $1.5 \times 10^{7}$ input cells were collected in the indicated gate (arrow). In vitro primed T cells were pooled and stained with a specific peptide CHMI ${ }^{319} / \mathrm{HLA}$-A*020I-multimer-PE and counterstained with an anti-human CD8-FITC mAb for cell sorting. Cell sorting was executed on a FACS Aria. (B) Sorted T cells were expanded using limiting dilution and screened for antigen specificity in IFN $\gamma$ ELISpot: T2 cells pulsed with CHMI ${ }^{319}$ (VIMPCSWWV), EZH2 ${ }^{666}$ (YMCSFLFNL) or as a control FLU (GILGFVFTL) peptide; T-cell lines screened for $\mathrm{CHMI}$ specificity; line 6, 12 and 17 were further expanded (left). T-cell lines screened for EZH2 specificity; lines II, I5 and 24 passed this screen (right). (C) Cos-7 cells were transiently transfected by lipofection with human HLA-A*020I cDNA and expression constructs with the gene of interest or GFP CDNA as an irrelevant control (left). HLA-A*020I-specific recognition of ET-cell lines (right). A673 cells are HLA-A*020I+ expressing the antigen whereas SBSR-AKS is an ET-cell line expressing the target antigen, but is negative for HLA-A*020I. IFN- $\gamma$ release was measured in triplicate. Error bars represent s.d. P-values $<0.05$ indicate significant difference (two-tailed t-tests were used). (D) Flow cytometric determination of peptide specificity of T-cell lines CHMI-6 (top panel) and EZH2-I5 (bottom panel) with specific peptide-multimers, irrelevant peptide-multimers served as a control. 

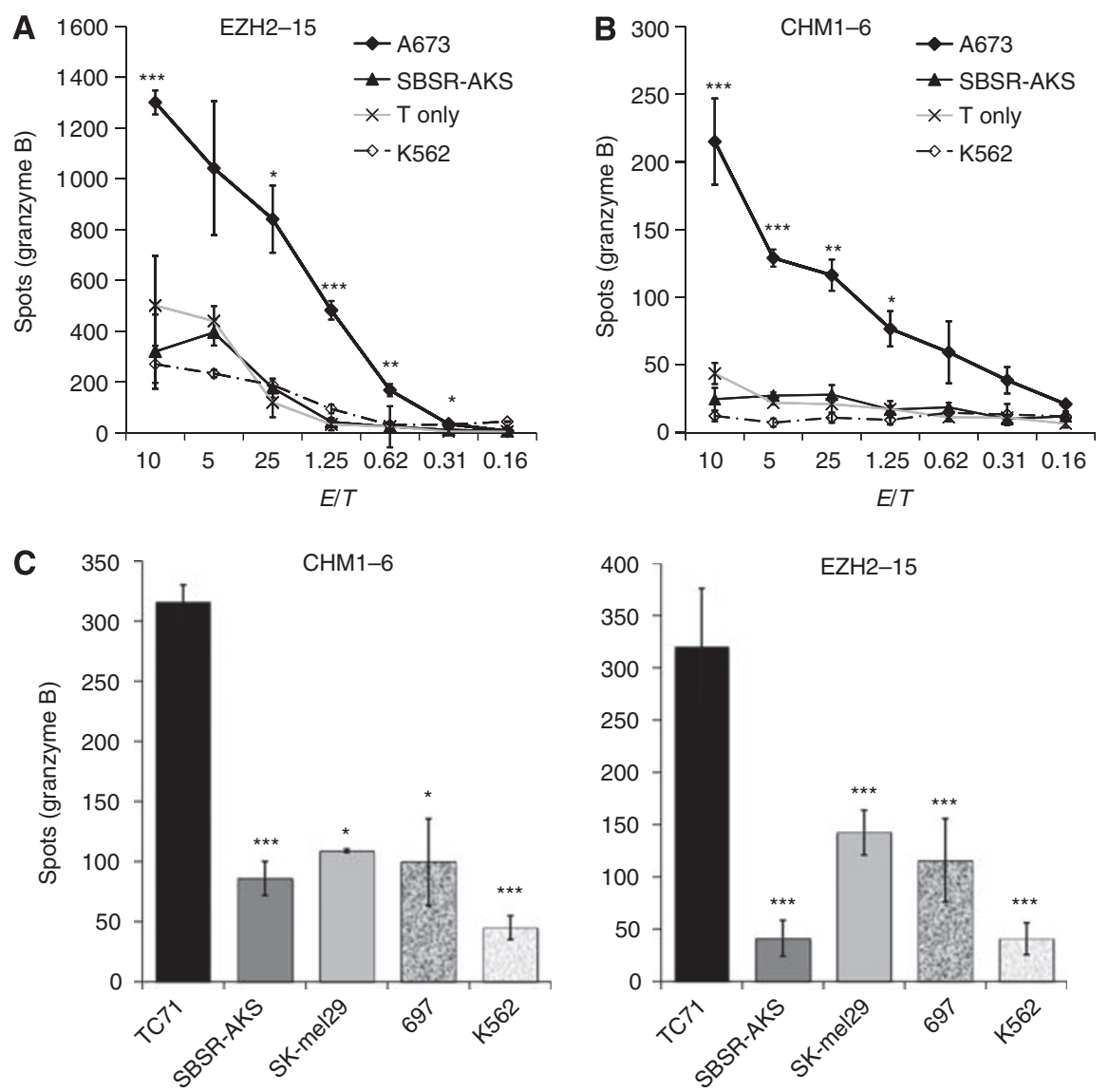

E/T ratio 10:1

Figure 3 Specific cytotoxicity of allo-restricted T cells directed against HLA-A020I ${ }^{+}$Ewing tumour cells. Cytotoxicity of allo-restricted T-cell lines was evaluated by target-specific granzyme B release in ELISpot assays. E/T: effector to target ratio. (A, B) A673: HLA-A*020I ${ }^{+}$ET-cell line; SBSR-AKS: HLA-A*020 I- ET-cell line; T only: spontaneous release of T-cell lines without target cells; K562: NK-cell control. (C) EZH2-specific line EZH2-I5 and $\mathrm{CHMI}$-specific line $\mathrm{CHMI}-6$ were retested at a defined $\mathrm{E} / \mathrm{T}$ ratio against selected cell lines to further evaluate their target specificity. TC-7I: $\mathrm{HLA}-\mathrm{A}^{*} 02 \mathrm{O}$ I ${ }^{+}$ ET; SK-Mel 29: HLA-A*020I + Melanoma; 697: HLA-A*020I ${ }^{+}$paediatric CALL. P-values $<0.05$ indicate significant difference. Asterisks indicate significance levels of (3A and 3B. Welch two sample t-Test) A673 lysis compared with SBSR-AKS lysis or (3C, two-tailed t-Test) TC7I lysis compared with respective control cell lines $(* P<0.05$; $* * P<0.01$; $* * * *<0.00$ I).
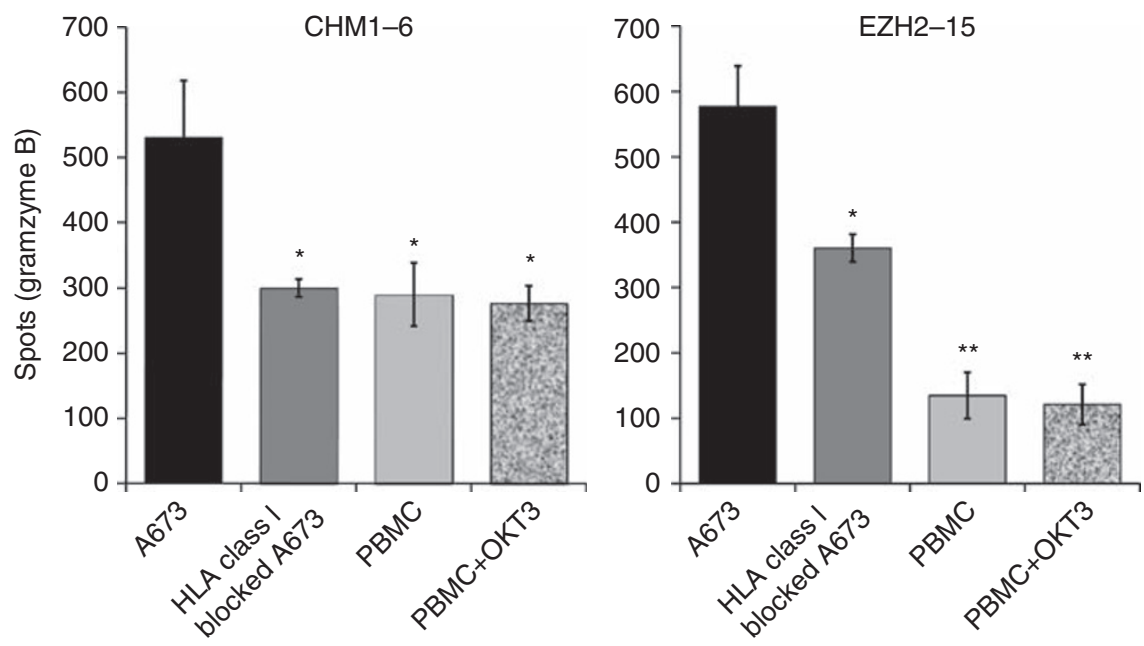

E/T ratio 5:1

Figure 4 Low granzyme B responses against HLA class I blocked A673, SBSR-AKS and HLA-A*020I+ PBMC compared with unblocked A673. HLA class I blocking before granzyme B ELISpots caused reversion of specific recognition by $\left.\mathrm{CHM}\right|^{319}$ or $\mathrm{EZH} 2^{666}$ peptide specific $\mathrm{CD} 8^{+} \mathrm{T}$ cells at an effector to target (E/T) ratio of 5:I. Granzyme B release upon contact with irradiated OKT3-stimulated/unstimulated HLA-A*020I ${ }^{+}$PBMC remained low compared with unblocked $\mathrm{A} 673$ at the same $E / T$ ratio. Asterisks indicate significance levels of $A 673$ lysis compared with respective controls (two-tailed $t$-test, $* P<0.05$; ** $P<0.01)$. 
Table I CHMI and EZH2-specific T-cell line data from five different donors

\begin{tabular}{|c|c|c|c|c|c|c|c|}
\hline $\begin{array}{l}\text { Donor } \\
\text { no. }\end{array}$ & Peptide & $\begin{array}{l}\text { Sorted } \\
\text { cells }\end{array}$ & $\begin{array}{l}\text { Tested } \\
\text { lines }\end{array}$ & $\begin{array}{l}\text { Best specified } \\
\text { T-cell lines }\end{array}$ & $\begin{array}{c}\text { T2+rel/irr peptide } \\
\text { mean of IFN } \gamma\end{array}$ & $\begin{array}{l}\text { A673/SBSR-AKS mean } \\
\text { of IFN } \gamma \text { or GB spots }\end{array}$ & $\begin{array}{c}\text { Expansion factor } \\
\text { after } 14 \text { days }\end{array}$ \\
\hline । & CHMI-319 & 1560 & 96 & $2^{\mathrm{a}}$ & 19.6 and 145 & $30.7(\mathrm{IFN} \gamma)$ & $80-100$ \\
\hline 2 & $E Z H 2-666$ & 5418 & 96 & $4^{a}$ & $1.8,57.8,490$ and 15 & $10.1(\mathrm{IFN} \gamma)$ & $100-140$ \\
\hline 3 & CHMI-319 & 590 & 48 & I & 5 & $4.9(\mathrm{~GB})$ & 17 \\
\hline 4 & CHMI-319 & 706 & 9 & 2 & 1.6 and 2.3 & 3.6 and $6.8(\mathrm{IFN} \gamma)$ & $22-24$ \\
\hline 5 & CHMI-319 & 2160 & 48 & 1 & 61.5 & II.I $(\mathrm{IFN} \gamma)$ & $50-80$ \\
\hline
\end{tabular}

Abbreviations: IFN $\gamma=$ interferon- $\gamma$; irr $=$ irrelevant; $\mathrm{GB}=$ granzyme $\mathrm{B}$; rel = relevant. ${ }^{\mathrm{a}}$ Only one cell line was further tested for $\mathrm{A} 673$ and $\mathrm{SBSR}-\mathrm{AKS}$ discrimination. $\mathrm{CD} 8^{+} \mathrm{T}$ Cells $\left(6 \times 10^{6}\right.$ to $\left.1 \times 10^{8}\right)$ from five different HLA-A*0201- healthy donors were stained and screened for the presence of $\mathrm{CHMI}{ }^{319}$ or $\mathrm{EZH} 2^{666}$ peptide-specific $\mathrm{CD} 8^{+} \mathrm{T}^{-}$cells after priming with peptide-loaded HLA-A*020I ${ }^{+}$dendritic cells. Expanded T-cell lines were tested for specificity in IFN $\gamma$ (and granzyme B for donor no. 3) ELISpot assays using T2 cells pulsed with either relevant or irrelevant peptides and A673 and SBSR-AKS Ewing tumour cell lines as targets with an ratio of I000 T cells/20 000 target cells (or 200000 T cells/ 20000 target cells in granzyme B assays). Numbers, specificity data and expansion rates are given.

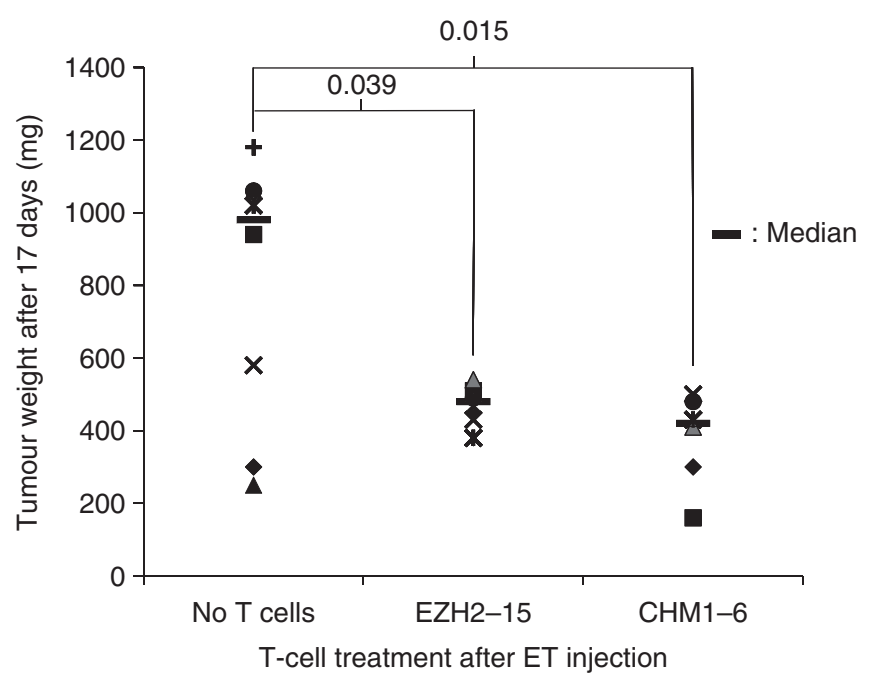

Figure 5 ET-specific $T$ cells delay tumour growth in Rag $2^{-1-} \gamma_{c}{ }^{-1-}$ mice after adoptive transfer. Rag $2^{-1-} \gamma^{-1-}$ mice were challenged s.c. intrainguinally with $2 \times 10^{6}$ EWS-FLII ${ }^{+} \mathrm{HLA}-\mathrm{A}^{*} 020 \mathrm{I}^{+} \mathrm{A} 673 \mathrm{ET}$ cells and received $2 \times 10^{6} \mathrm{CHMI}^{319}$ or $\mathrm{EZH} 2^{666}$-specific $T$ cells by i.v. injection 3 days later. Mice were killed and analysed on day 17. Individual mice are represented by symbols. Median tumour weights are indicated by black bars. A $P$-value $<0.05$ indicates a significant difference between tumour weights of mice treated with EZH2-15 or CHMI-6 compared with controls (Welch two sample t-test).

only minimally detected by these allo-restricted $\mathrm{T}$ cells, supporting HLA-A ${ }^{*} 0201$-restricted antigen-specific cytotoxicity of our selected T-cell lines (all $P<0.05$, two-tailed $t$-test; Figure 4 ). General feasibility of this approach was further demonstrated by our ability to identify and sufficiently expand several of such T-cell lines derived of five independent donors tested (Table 1).

\section{ET-specific T cells delay tumour growth in $\operatorname{Rag}^{-I-} \gamma_{\mathrm{C}}{ }^{-I-}$ mice after adoptive transfer}

To analyse whether such allo-restricted cytotoxic $\mathrm{T}$ cells can inhibit tumour growth in vivo, we challenged $\mathrm{Rag}^{-1-} \gamma_{\mathrm{C}}{ }^{-1-}$ mice s.c. intra-inguinally with EWS-FLI ${ }^{+}$HLA-A $^{\star} 0201^{+}$A673 ET cells, followed by i.v. injection of EZH2 $(n=7)$ or CHM1 $(n=6)$ specific T cells 3 days later (see Materials and Methods). Control mice $(n=8)$ did not receive T-cell treatment. Median tumour weights of mice receiving $\mathrm{T}$ cells were significantly lower compared with control mice $(P=0.015$ for EZH2- and 0.039 for CHM1 study group, respectively, compared with controls, Welch two sample $t$-test; Figure 5). None of the treated mice showed any signs of GvHD upon analysis.

\section{DISCUSSION}

Ewing tumour are highly malignant tumours of neuroectodermal or endothelial origin (Schmidt et al, 1985; Staege et al, 2004) and are molecularly defined by ews/ets translocations. In all, $85 \%$ of ET are characterized by a specific EWS-FLI1 translocation fusing the gene coding for the ribosomal binding protein EWS to the gene coding for the transcription factor FLI1. The resulting chimeric transcription factor has been implicated in tumour genesis and is tumour-specific (Kovar, 1998; de Alava and Gerald, 2000). However, despite an MHC class II restricted peptide derived from the fusion region of EWS-FLI1 that is able to initiate a CD4 ${ }^{+} \mathrm{T}$-cell response (Meyer-Wentrup et al, 2005), no immunogenic ET-specific MHC class I binding peptide derived from this fusion region has been identified yet. To further determine possible ET-specific immunogenic peptides, we utilised high-density DNA microarrays for the identification of ET-specific gene expression profiles in comparison with 133 normal tissues of diverse origin (normal body atlas, NBA) and identified 37 genes that were highly upregulated or specifically expressed in ET (Staege et al, 2004). Of these, CHM1 and EZH2 revealed specific or at least strong overexpression in ET.

Chondromodulin-I is a glycoprotein that is normally expressed mainly in immature cartilage, stimulating proteoglycan and DNA synthesis, proliferation and differentiation of chondrocytes. It inhibits angiogenesis in vitro and in vivo (Hiraki et al, 1997, 1999). The overexpression of such a molecule in a malignant tumour is surprising, but may be associated with the reduced microvessel density in ET and the observation that an increased aggressiveness of hypoxic tumour cells may correlate with increased metastasis and inferior prognosis (Dunst et al, 2001). Chondromodulin-I was previously not known to be tumour-associated.

Enhancer of Zeste, Drosophila Homolog 2 is part of the polycomb repressor complex 2 (PRC2) and within this complex it silences target genes by methylating lysine 27 on histone 3 (H3K27). Enhancer of Zeste, Drosophila Homolog 2 is already active at gastrulation (Sparmann and van Lohuizen, 2006). We found EWS-FLI1 to be bound to the EZH2 promoter in vivo, inducing EZH2 expression in ET and mesenchymal stem cells. Downregulation of EZH2 by RNA interference suppressed ET tumour development and metastasis in immunodeficient Rag2 ${ }^{-l-} \gamma_{\mathrm{C}}{ }^{-1-}$ mice. Enhancer of Zeste, Drosophila Homolog 2 maintained an undifferentiated stemness phenotype in ET (Richter et al, 2009), implicating that EZH2 might have a central role in ET pathology (Burdach et al, 2009). Enhancer of Zeste, Drosophila Homolog 2 upregulation is known to be associated with poor prognosis in prostate cancer (Varambally et al, 2002). As polycomb group proteins are known to be vitally involved in transcriptional control and carcinogenesis in several human tumours (Simon and Lange, 2008), EZH2 may be less susceptible to the development of immune escape variants. Peptide EZH2 ${ }^{666}$ 
was already validated as a target for cancer immunotherapy (Steele et al, 2006).

Mixed results have been observed with autologous SCT for patients with high risk or recurrent ET. Whereas some studies reported improved disease free survival over historical controls (Burdach et al, 1991, 2003; Paulussen et al, 1998; Burdach, 2004), others observed no long-term benefit compared with conventional therapies (Cotterill et al, 2000; Meyers et al, 2001). These findings emphasise the need for alternative approaches. In ET patients with vast bone affection and poor prognosis, allogeneic SCT is a therapy option (Burdach et al, 2000; Koscielniak et al, 2005; Lucas et al, 2008). However, the desired GvT effect is intrinsically tied to an often-pronounced GvHD, mediated by allo-reactive $\mathrm{T}$ cells. To specifically direct such $\mathrm{T}$ cells against the tumour, it is necessary to identify the allo-restricted tumour-specific $\mathrm{T}$ cells within an allogeneic T-cell population (Dutoit et al, 2002; Mutis et al, 2002; Amrolia et al, 2003; Whitelegg et al, 2005; Schuster et al, 2007).

A recent retrospective study based on data drawn from the EBMT-, PRST-, APBMT-, and MetaEICESS-registries revealed that there is no improvement of survival of ET patients receiving reduced intensity conditioning compared with high-dose conditioning before allogeneic stem cell transplantation with HLA-matched grafts, implicating absence of a clinically relevant graft $v s$ ET effect (Thiel et al, 2011). Reduced intensity conditioning regimen followed by haploidentical stem cell transplantation is subject to various ongoing prospective trials and may increasingly replace HLA-matched approaches. Thus, HLA-A ${ }^{\star} 0201^{+}$ET patients may profit from a treatment based on adoptive transfer from ET-specific $\mathrm{T}$ cells of an HLA-A ${ }^{\star} 0201^{-}$donor after haploidentical stem cell transplantation.

We isolated allo-restricted $\mathrm{T}$ cells by $\mathrm{MHC}$ multimer-staining and cell sorting. Using this technique, we have succeeded in establishing T-cell lines directed against several HLA-A ${ }^{\star} 0201-$ restricted peptides derived from ET-specific antigens. Reliable in silico prediction algorithms are helpful tools to identify a CTL epitope (Larsen et al, 2005). Still, in silico high scoring epitope candidates have to be confirmed for binding to HLA-A ${ }^{\star} 0201$. We not only verified the already published $\mathrm{EZH} 2{ }^{666}$ peptide as a binding peptide on T2 cells (Steele et al, 2006), but identified $\mathrm{CHM}^{319}$ as a new good binding peptide (Supplementary Figure 1). As $\mathrm{CHM}^{319}$ had been a previously undescribed peptide, it could have been possible that it represented an artificial epitope. Therefore, the simian cell line Cos-7 was co-transfected with vectors containing the human HLA- $A^{*} 0201$ gene and the gene of interest. Again, not only the EZH2 ${ }^{666}$ peptide-specific $\mathrm{T}$ cells recognised such double-transfected Cos-7 cells, but also the $\mathrm{CHM}^{319}$ peptide-specific T cells specifically released IFN $-\gamma$ when contacting Cos-7 co-transfected cells, indicating processivity of these peptide epitopes. Even though EZH2 is expressed at a low level on a variety of tissues compared with CHM1, it may nevertheless constitute an appropriate target for T-cell therapy after successful engraftment, because of its particularly high expression in ET. The risk of GvHD caused by EZH $2^{666}$-specific T cells is likely to be lower than the risk associated with infusion of blunt donor lymphocytes. Nevertheless, CHM1 represents a more appropriate target and further ET-specific targets remain to be identified and tested.

The $\mathrm{T}$ cells isolated here not only specifically recognised peptidepulsed or antigen-transfected cells in the context of HLA-A*0201, but also released granzyme $\mathrm{B}$ when recognising $\mathrm{HLA}-\mathrm{A}^{\star} 0201^{+} \mathrm{ET}$ expressing the antigen, while other HLA-A*0201 ${ }^{+}$tumour lines and HLA- $A^{\star} 0201$ negative ET were not affected. Furthermore, efficacy of allo-restricted $\mathrm{EZH}_{2}{ }^{666}$ and/or $\mathrm{CHM}^{319}$ specific $\mathrm{T}$ cells were confirmed in a xenograft mouse model, where ET growth was significantly delayed after adoptive transfer of such $\mathrm{T}$ cells compared with controls and GvHD was absent.

Although we could demonstrate the general feasibility of our approach, with which we were able to generate allo-restricted ET-specific $\mathrm{T}$ cells in sufficient numbers of every donor tested, long-term persistence of our $\mathrm{T}$ cells in vivo has not been analyzed, but may be further investigated in a humanised mouse model (Traggiai et al, 2004). Future approaches generating ET-specific T cells against $\mathrm{EZH} 2^{666}$ and/or $\mathrm{CHM}^{319}$ with a central memory (CM) phenotype (Berger et al, 2008) in addition may yield improved anti-tumour efficacy. Furthermore, TCR identification, cloning and transfection into donor $\mathrm{CM} \mathrm{CD} 8{ }^{+} \mathrm{T}$ cells before adoptive transfer may constitute an appropriate tool to simplify the generation procedure to obtain ET-specific T cells.

However, the generation of highly specific and efficacious allo-restricted $\mathrm{T}$ cells here already yet opens the avenue for new therapeutic strategies in allogeneic stem cell and effector-cell transplantation in the treatment of ET patients.

\section{ACKNOWLEDGEMENTS}

We thank Colette Zobywalski, Katleen Götsch and Lynette Henkel for expert technical assistance. Petra Wolf is acknowledged for statistical advice and Thomas Grünewald for critical reading of the manuscript and for helpful discussions. This work was supported by unrestricted special grants from the Else-Kröner-Fresenius Stiftung (P31/08//A123/07) and the Deutsche Kinderkrebsstiftung (DKS 2010.07) to GHSR and SB; the Bayerisches Staatsministerium für Wissenschaft und Kunst (KKF8739175), the Wilhelm-Sander Stiftung (2006.109.1) to SB, and (2009.901.1) to GHSR and SB and the Helmholtz Alliance Immunotherapy of Cancer and the Deutsche Forschungsgemeinschaft (1579/4-1) to HB It is part of the Translational Sarcoma Research Network supported by the Bundesministerium für Bildung und Forschung (BMBF, FK 01GM0870 to GHSR and SB). ELISpot reader was kindly sponsored by the Rotary Club München-Blutenburg. UT and SP equally contributed to this work that contains part of the doctoral thesis of SP.

\section{Conflict of interest}

The authors declare no conflict of interest.

Supplementary Information accompanies the paper on British Journal of Cancer website (http://www.nature.com/bjc)

\section{REFERENCES}

Amrolia PJ, Reid SD, Gao L, Schultheis B, Dotti G, Brenner MK, Melo JV Goldman JM, Stauss HJ (2003) Allorestricted cytotoxic T cells specific for human CD45 show potent antileukemic activity. Blood 101(3): $1007-1014$

Anderson MJ, Shafer-Weaver K, Greenberg NM, Hurwitz AA (2007) Tolerization of tumor-specific $\mathrm{T}$ cells despite efficient initial priming in a primary murine model of prostate cancer. J Immunol 178(3): $1268-1276$
Berger C, Jensen MC, Lansdorp PM, Gough M, Elliott C, Riddell SR (2008) Adoptive transfer of effector CD8+ T cells derived from central memory cells establishes persistent T cell memory in primates. J Clin Invest 118(1): $294-305$

Borg NA, Ely LK, Beddoe T, Macdonald WA, Reid HH, Clements CS, Purcell AW, Kjer-Nielsen L, Miles JJ, Burrows SR, McCluskey J, Rossjohn J (2005) The CDR3 regions of an immunodominant $\mathrm{T}$ cell receptor dictate the 'energetic landscape' of peptide-MHC recognition. Nat Immunol 6(2): $171-180$ 
Burdach S (2004) Treatment of advanced Ewing tumors by combined radiochemotherapy and engineered cellular transplants. Pediatr Transplant 8(Suppl 5): 67-82

Burdach S, Meyer-Bahlburg A, Laws HJ, Haase R, van Kaik B, Metzner B, Wawer A, Finke R, Gobel U, Haerting J, Pape H, Gadner H, Dunst J, Juergens H (2003) High-dose therapy for patients with primary multifocal and early relapsed Ewing's tumors: results of two consecutive regimens assessing the role of total-body irradiation. J Clin Oncol 21(16): $3072-3078$

Burdach S, Peters C, Paulussen M, Nurnberger W, Wurm R, Wernet P, Dilloo D, Voehringer R, Gadner H, Gobel U, Jurgens H (1991) Improved relapse free survival in patients with poor prognosis Ewing's sarcoma after consolidation with hyperfractionated total body irradiation and fractionated high dose melphalan followed by high dose etoposide and hematopoietic rescue. Bone Marrow Transplant 7(Suppl 2): 95

Burdach S, Plehm S, Unland R, Borkhardt A, Staege MS, Müller-Tidow C, Richter GHS (2009) Epigenetic maintenance of stemness and malignancy in peripheral neuroectodermal tumors by EZH2. Cell Cycle 8(13): $1991-1996$

Burdach S, Thiel U, Schoniger M, Haase R, Wawer A, Nathrath M, Kabisch H, Urban C, Laws HJ, Dirksen U, Steinborn M, Dunst J, Jurgens H (2010) Total body MRI-governed involved compartment irradiation combined with high-dose chemotherapy and stem cell rescue improves long-term survival in Ewing tumor patients with multiple primary bone metastases. Bone Marrow Transplant 45(3): 483-489

Burdach S, van Kaick B, Laws HJ, Ahrens S, Haase R, Korholz D, Pape H, Dunst J, Kahn T, Willers R, Engel B, Dirksen U, Kramm C, Nurnberger W, Heyll A, Ladenstein R, Gadner H, Jurgens H, Go el U (2000) Allogeneic and autologous stem-cell transplantation in advanced Ewing tumors. An update after long-term follow-up from two centers of the European Intergroup study EICESS. Stem-Cell Transplant Programs at Dusseldorf University Medical Center, Germany and St. Anna Kinderspital, Vienna, Austria. Ann Oncol 11(11): 1451-1462

Childs R, Chernoff A, Contentin N, Bahceci E, Schrump D, Leitman S, Read EJ, Tisdale J, Dunbar C, Linehan WM, Young NS, Barrett AJ (2000) Regression of metastatic renal-cell carcinoma after nonmyeloablative allogeneic peripheral-blood stem-cell transplantation. $N$ Engl J Med 343(11): $750-758$

Cotterill SJ, Ahrens S, Paulussen M, Jurgens HF, Voute PA, Gadner H, Craft AW (2000) Prognostic factors in Ewing's tumor of bone: analysis of 975 patients from the European Intergroup Cooperative Ewing's Sarcoma Study Group. J Clin Oncol 18(17): 3108-3114

de Alava E, Gerald WL (2000) Molecular biology of the Ewing's sarcoma/ primitive neuroectodermal tumor family. J Clin Oncol 18(1): 204-213

Dunst J, Ahrens S, Paulussen M, Burdach S, Jurgens H (2001) Prognostic impact of tumor perfusion in MR-imaging studies in Ewing tumors. Strahlenther Onkol 177(3): 153-159

Dutoit V, Guillaume P, Romero P, Cerottini JC, Valmori D (2002) Functional analysis of HLA-A ${ }^{*} 0201 /$ Melan-A peptide multimer+ CD8+ $\mathrm{T}$ cells isolated from an HLA-A ${ }^{\star} 0201$ - donor: exploring tumor antigen allorestricted recognition. Cancer Immun 2: 7

Felix NJ, Allen PM (2007) Specificity of T-cell alloreactivity. Nat Rev Immunol 7(12): $942-953$

Hiraki Y, Inoue H, Iyama K, Kamizono A, Ochiai M, Shukunami C, Iijima S, Suzuki F, Kondo J (1997) Identification of chondromodulin I as a novel endothelial cell growth inhibitor. Purification and its localization in the avascular zone of epiphyseal cartilage. J Biol Chem 272(51): $32419-32426$

Hiraki Y, Mitsui K, Endo N, Takahashi K, Hayami T, Inoue H, Shukunami C, Tokunaga K, Kono T, Yamada M, Takahashi HE, Kondo J (1999) Molecular cloning of human chondromodulin-I, a cartilage-derived growth modulating factor, and its expression in Chinese hamster ovary cells. Eur J Biochem 260(3): 869-878

Kolb HJ, Schattenberg A, Goldman JM, Hertenstein B, Jacobsen N, Arcese W, Ljungman P, Ferrant A, Verdonck L, Niederwieser D, van Rhee F, Mittermueller J, de Witte T, Holler E, Ansari H (1995) Graftversus-leukemia effect of donor lymphocyte transfusions in marrow grafted patients. Blood 86(5): 2041-2050

Koscielniak E, Gross-Wieltsch U, Treuner J, Winkler P, Klingebiel T, Lang P, Bader P, Niethammer D, Handgretinger R (2005) Graft-versusEwing sarcoma effect and long-term remission induced by haploidentical stem-cell transplantation in a patient with relapse of metastatic disease. $J$ Clin Oncol 23(1): $242-244$

Kovar H (1998) Progress in the molecular biology of Ewing tumors. Sarcoma 2(1): 3-17
Larsen MV, Lundegaard C, Lamberth K, Buus S, Brunak S, Lund O, Nielsen M (2005) An integrative approach to CTL epitope prediction: a combined algorithm integrating MHC class I binding, TAP transport efficiency, and proteasomal cleavage predictions. Eur J Immunol 35(8): $2295-2303$

Lucas KG, Schwartz C, Kaplan J (2008) Allogeneic stem cell transplantation in a patient with relapsed Ewing sarcoma. Pediatr Blood Cancer 51(1): $142-144$

Meyer-Wentrup F, Richter G, Burdach S (2005) Identification of an immunogenic EWS-FLI1-derived HLA-DR-restricted $\mathrm{T}$ helper cell epitope. Pediatr Hematol Oncol 22(4): 297-308

Meyers PA, Krailo MD, Ladanyi M, Chan KW, Sailer SL, Dickman PS, Baker DL, Davis JH, Gerbing RB, Grovas A, Herzog CE, Lindsley KL, Liu-Mares W, Nachman JB, Sieger L, Wadman J, Gorlick RG (2001) High-dose melphalan, etoposide, total-body irradiation, and autologous stem-cell reconstitution as consolidation therapy for high-risk Ewing's sarcoma does not improve prognosis. J Clin Oncol 19(11): $2812-2820$

Moosmann A, Khan N, Cobbold M, Zentz C, Delecluse HJ, Hollweck G, Hislop AD, Blake NW, Croom-Carter D, Wollenberg B, Moss PA, Zeidler R, Rickinson AB, Hammerschmidt W (2002) B cells immortalized by a mini-Epstein-Barr virus encoding a foreign antigen efficiently reactivate specific cytotoxic T cells. Blood 100(5): 1755 - 1764

Moris A, Teichgraber V, Gauthier L, Buhring HJ, Rammensee HG (2001) Cutting edge: characterization of allorestricted and peptide-selective alloreactive $\mathrm{T}$ cells using HLA-tetramer selection. J Immunol 166(8): $4818-4821$

Mutis T, Blokland E, Kester M, Schrama E, Goulmy E (2002) Generation of minor histocompatibility antigen HA-1-specific cytotoxic $\mathrm{T}$ cells restricted by nonself HLA molecules: a potential strategy to treat relapsed leukemia after HLA-mismatched stem cell transplantation. Blood 100(2): 547-552

Parker KC, Bednarek MA, Coligan JE (1994) Scheme for ranking potential HLA-A2 binding peptides based on independent binding of individual peptide side-chains. J Immunol 152(1): 163 - 175

Paulussen M, Ahrens S, Burdach S, Craft A, Dockhorn-Dworniczak B, Dunst J, Frohlich B, Winkelmann W, Zoubek A, Jurgens H (1998) Primary metastatic (stage IV) Ewing tumor: survival analysis of 171 patients from the EICESS studies. European Intergroup Cooperative Ewing Sarcoma Studies. Ann Oncol 9(3): 275-281

Rammensee H, Bachmann J, Emmerich NP, Bachor OA, Stevanovic S (1999) SYFPEITHI: database for MHC ligands and peptide motifs. Immunogenetics 50(3-4): 213-219

Richter GH, Plehm S, Fasan A, Rossler S, Unland R, Bennani-Baiti IM, Hotfilder M, Lowel D, von Luettichau I, Mossbrugger I, QuintanillaMartinez L, Kovar H, Staege MS, Muller-Tidow C, Burdach S (2009) EZH2 is a mediator of EWS/FLI1 driven tumor growth and metastasis blocking endothelial and neuro-ectodermal differentiation. Proc Natl Acad Sci USA 106(13): 5324-5329

Rosenberg SA, Restifo NP, Yang JC, Morgan RA, Dudley ME (2008) Adoptive cell transfer: a clinical path to effective cancer immunotherapy. Nat Rev Cancer 8(4): 299-308

Schmidt D, Harms D, Burdach S (1985) Malignant peripheral neuroectodermal tumours of childhood and adolescence. Virchows Arch A Pathol Anat Histopathol 406(3): 351-365

Schuster IG, Busch DH, Eppinger E, Kremmer E, Milosevic S, Hennard C, Kuttler C, Ellwart JW, Frankenberger B, Nossner E, Salat C, Bogner C, Borkhardt A, Kolb HJ, Krackhardt AM (2007) Allorestricted T cells with specificity for the FMNL1-derived peptide PP2 have potent antitumor activity against hematologic and other malignancies. Blood 110(8): $2931-2939$

Shafer-Weaver K, Sayers T, Strobl S, Derby E, Ulderich T, Baseler M, Malyguine A (2003) The Granzyme B ELISPOT assay: an alternative to the $51 \mathrm{Cr}$-release assay for monitoring cell-mediated cytotoxicity. J Transl Med 1(1): 14

Simon JA, Lange CA (2008) Roles of the EZH2 histone methyltransferase in cancer epigenetics. Mutat Res 647(1-2): 21-29

Sparmann A, van Lohuizen M (2006) Polycomb silencers control cell fate, development and cancer. Nat Rev Cancer 6(11): 846-856

Staege MS, Hutter C, Neumann I, Foja S, Hattenhorst UE, Hansen G, Afar D, Burdach SE (2004) DNA microarrays reveal relationship of Ewing family tumors to both endothelial and fetal neural crest-derived cells and define novel targets. Cancer Res 64(22): 8213-8221

Steele JC, Torr EE, Noakes KL, Kalk E, Moss PA, Reynolds GM, Hubscher SG, van Lohuizen M, Adams DH, Young LS (2006) The polycomb group 
proteins, BMI-1 and EZH2, are tumour-associated antigens. Br J Cancer 95(9): $1202-1211$

Thiel U, Wawer A, Wolf P, Badoglio M, Santucci A, Klingebiel T, Basu O, Borkhardt A, Laws HJ, Kodera Y, Yoshimi A, Peters C, Ladenstein R, Pession A, Prete A, Urban EC, Schwinger W, Bordigoni P, Salmon A, Diaz MA, Afanasyev B, Lisukov I, Morozova E, Toren A, Bielorai B, Korsakas J, Fagioli F, Caselli D, Ehninger G, Gruhn B, Dirksen U, Abdel-Rahman F, Aglietta M, Mastrodicasa E, Torrent M, Corradini P, Demeocq F, Dini G, Dreger P, Eyrich M, Gozdzik J, Guilhot F, Holler E, Koscielniak E, Messina C, Nachbaur D, Sabbatini R, Oldani E, Ottinger H, Ozsahin H, Schots R, Siena S, Stein J, Sufliarska S, Unal A, Ussowicz $M$, Schneider $P$, Woessmann $W$, Jürgens $H$, Bregni $M$, Burdach S (2011) No improvement of survival with reduced versus high intensity conditioning for allogeneic stem cell transplants in Ewing Tumor Patients. Ann Oncol; e-pub ahead of print 18 January 2011

Traggiai E, Chicha L, Mazzucchelli L, Bronz L, Piffaretti JC, Lanzavecchia A, Manz MG (2004) Development of a human adaptive immune system in cord blood cell-transplanted mice. Science 304(5667): 104-107

Varambally S, Dhanasekaran SM, Zhou M, Barrette TR, Kumar-Sinha C, Sanda MG, Ghosh D, Pienta KJ, Sewalt RG, Otte AP, Rubin MA, Chinnaiyan AM (2002) The polycomb group protein EZH2 is involved in progression of prostate cancer. Nature 419(6907): 624-629

Whitelegg AM, Oosten LE, Jordan S, Kester M, van Halteren AG, Madrigal JA, Goulmy E, Barber LD (2005) Investigation of peptide involvement in $\mathrm{T}$ cell allorecognition using recombinant HLA class I multimers. J Immunol 175(3): $1706-1714$ 